\title{
脳腫瘍不全麻疩患者に対する局甲骨アライメントへの 介入が立位姿勢，歩行能力へ及ぼす効果
}

\author{
Effect of Interventions for Scapula Alignment on the Posture and Walking Ability \\ of a Patient with Incomplete Paralysis after Brain Tumor: A Case Study
}

矢田 拓也 ${ }^{1)}$ 川崎 翼 ${ }^{2)}$ 大平 雅弘 $^{3)}$

TAKUYa YADA, RPT ${ }^{1)}$, Tsubasa KAWASAKI, RPT, PhD ${ }^{2)}$, MASAhIRo OHIRA, OTR, MSc ${ }^{3)}$

${ }^{1)}$ Department of Rehabilitation, National Hospital Organization, Yokohama Medical Center: 3-60-2 Harajuku, Totsuka-ku, Yokohama-shi, Kanagawa 245-8575, Japan TEL +81 45-851-2621 E-mail: yada51111102@yahoo.co.jp

${ }^{2)}$ Faculty of Human Sociology, Tokyo International University

3) Department of Rehabilitation, Yokohama Shin-midori General Hospital

Rigakuryoho Kagaku 33(5): 845-850, 2018. Submitted May 7, 2018. Accepted Jun. 22, 2018.

\begin{abstract}
Purpose] To investigate the effects of realignment of both scapulas on the postural and walking stability and walking efficiency of a patient with upper limb paralysis. [Participants and Methods] A patient showed postural and walking instability due to left upper limb paralysis after brain tumorectomy. For the realignment of his scapulas, stabilization training of the scapulothoracic joint was performed for 40 minutes per day for 5 days. The postural and walking stability, and walking efficiency were assessed pre- and post-training. [Results] After the training, the alignment of the scapulas was corrected, and the postural and walking stability and walking efficiency had improved compared to pre-training. [Conclusion] This result suggests that realignment of the scapulas improves the postural and walking stability and walking efficiency of patients with paralysis.
\end{abstract}

Key words: brain tumor, alignment at scapulas, balance function

要旨：〔目的〕肩甲骨アライメントを修正することを目的とした介入による, 脳腫瘍患者のバランス機能, 歩行能力 の改善効果を検討した。【対象と方法〕左上下肢不全麻疩により歩行不安定性を呈した脳腫瘍患者 1 名に対し, 肩甲 胸郭関節の安定化訓練と立位, 歩行訓練を 40 分の介入で 5 日間行わせた。肩甲骨アライメント, 立位時の身体重心, バランス, 歩行評価から治療効果を検証した。〔結果〕介入によって, 立位, 歩行時の肩甲骨アライメントは修正され, バランス機能, 歩行能力は向上した。〔結語〕脳腫瘍不全麻瘏患者に対して肩甲骨アライメントを修正する運動療法は, バランス機能, 歩行能力向上に有効であることが示唆された.

キ一ワード : 脳腫瘍, 肩甲骨アライメント, バランス機能

1)独立行政法人国立病院機構＼cjkstart横浜医療センターリハビリテーション科：神奈川県横浜市戸塚区原宿 3-60-2（テ245-8575） TEL 045-851-2621

2) 東京国際大学 人間社会学部 スポーツ医科学機構

3) 横浜新緑総合病院 リハビリテーション部

受付日 2018 年 5 月 7 日 受理日 2018 年 6 月 22 日 


\section{I.はじめに}

人間にとって歩行は, 神経筋機能が高次に統制されて 可能となる最も重要な移動手段である，歩行を効率的に 行うために, 体幹アライメントの重要性が指摘されてい る. 坂光ら 1) は脊柱後弯変形と歩行能力の関係について 後弯変形が強いほど 3 分間歩行距離が減少したと報告し ている。また，体幹アライメントが異常であると，その 他の関節を代償的に使用するため, 歩行効率や安定性が 低下するという報告もある 2,3). そのため歩行を効率的 かつ安定して行うためには，体幹アライメントに着目す る必要性があるといえる。

吉田ら ${ }^{4)}$ は, 健常成人 40 名の立位時の肩甲骨と胸椎 屈曲角度を測定したところ, 肩甲骨外転角度が増加して いた者は, 胸椎屈曲角度も増加していたと報告してい る. また, 市川ら 5) は健常成人 32 名の上肢アライメン トの姿勢分類を行い, 胸椎屈曲角度が増加していた者は, 肩甲骨外転角度も増加していたと報告している。ささらに 冨田 6) は, 中枢神経疾患患者は肩甲骨周囲筋の弛緩性 麻痺や筋緊張の不均衡により, 局甲胸郭関節の機能不全 を伴う症例が多いと報告している。これらのことから， 立位時の肩甲骨アライメントの変化に伴い, 体幹アライ メントも変化する可能性が示唆される.

近年，肩甲骨アライメントに着目した介入が複数報告 されている，片麻痺患者に対して肩甲骨アライメントを 適正化する効果のある装具を装着し, その前後で歩行速 度, 歩行率を比較したところ, 装着後のほうが歩行能力 は改善したとの報告がなされている7,8)。また Hesse ${ }^{9)}$ は、 片麻瘏患者に上肢懸垂用肩関節装具を装着した結果, 麻 痺側下肢への荷重量が増加し, 立脚時間が延長したこと を報告している。これらの肩関節装具を用いた介入研究 から, 歩行安定性の向上を目的に肩甲骨アライメントに 着目することの重要性が示唆されている.

今回, 脳腫瘍によって左上下肢不全麻痺による歩行不 安定性を呈した患者に対して肩甲骨アライメントを中心 に評価し，運動療法や徒手的介入により肩甲骨アライメ ントの改善が歩行能力向上につながったため報告する.

\section{II. 対象と方法}

\section{1. 対象}

症例は 60 代の男性で, 2 週間前より歩行時の左側へ のふらつきが出現し，当院を受診した，右前頭葉の膠芽 腫の診断を受け，脳腫掦摘出術を実施したが，術後に左 上下肢の運動麻痺が残存した。術後 3 日目よりリハビリ 介入を開始した，基本動作に関しては，端座位は自立， 立ち上がり，立位，歩行は見守りで行っていた，元の職 業は農家で歩くことが多かった。症例の HOPE は庭を 歩きたいであったため, NEED は歩行安定性, 効率性
の向上とした。なお，今回の報告については横浜医療セ ンター倫理委員会より承認を得ている。また症例本人に 目的, 方法, 研究結果の取り扱い等に関して説明し同意 を得ている。

\section{2. 理学療法評価}

術後 5 日目に初期評価を行った。意識レベルは, Japan Coma Scale（以下, JCS) で 1 であった。言語理解, 表出ともに問題はなかった. Frontal Assessment Battery は 16/18 点であり, 若干の前頭葉機能の低下を認めたが, 訓練実施に扔いて大きな弊害をもたらすことはなかっ た。その他の高次脳機能に関しては, 大きな問題はみら れなかった，症例の術前，術後の CT 画像を図 1 に示す。

立位時の身体重心については，矢状面上の基本的立位 姿勢の理想的アライメントは耳垂, 肩峰, 大転子, 膝関 節前部，外果の前方が垂直線上に存在する10) といわれ ているが, 本症例に抢いては, 床面と外果前方の垂直線 より耳垂は前方に位置していたことから，本症例の身体 重心は前方に位置していたと判断した（図2）。介入前 後の立位時の身体重心の変化を追うために, 症例の側方 から撮影した写真を画像処理・解析ソフトウェア ImageJ を用いて床面と外果前方の垂直線から耳垂まで の距離を測定したところ， $0.5 \pm 0.01 \mathrm{~cm}$ であった。 ま た，立位時の胸椎アライメントを測定するために，第 1 胸椎棘突起から第 12 胸椎棘突起までの直線距離を入 ジャーで測定し, $36.1 \pm 0.12 \mathrm{~cm}$ (平均值 \pm 標準偏差) であった。 上記二つの検査に関しては, 3 回測定を行い 平均值を記載した。

立位時の各関節のアライメントは, 胸椎は屈曲位, 右 側屈位, 右回旋位, 腰椎は左側屈位, 左回旋位, 左股関 節は外転位, 屈曲位, 左滕関節は屈曲位, 左足関節は背 屈位であった，立位保持中の筋緊張に関しては，触診に て左右差を比較し評価を行い, 左僧帽筋上部線維の筋緊 張え進, 左僧帽筋中部線維, 下部線維, 左前鋸筋, 左菱
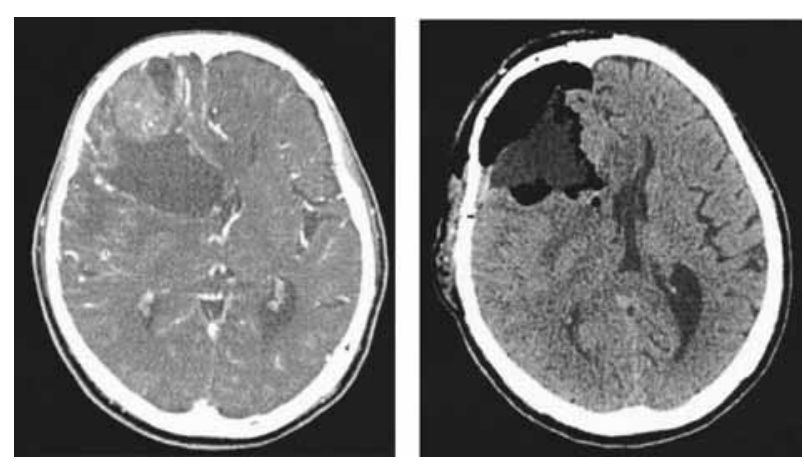

図1 症例の CT画像 (左：術前, 右 : 術後)

術前は，右前頭葉に膠芽腫と思われる低吸収域を認め る. 術後は,腫揚摘出術により空洞形成がなされている。 また脳浮腫と思われる低吸収域を認める。 

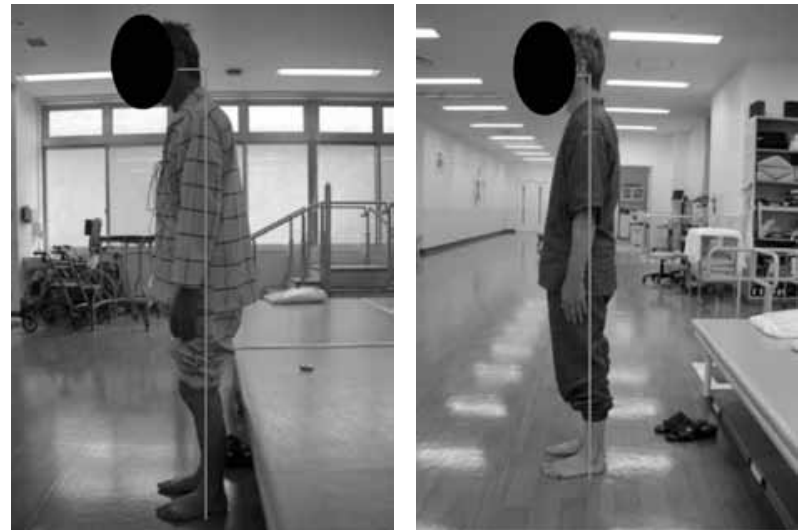

図2 介入前後の立位 (左 : 介入前, 右 : 介入後)

介入前は, 左肩甲骨は外転, 挙上, 上方回旋し, 胸椎 は後弯，右側屈，右回旋を呈し，身体重心は左前方に 位置していた，介入後は，左肩甲骨の外転，挙上，上 方回旋, 胸椎の後弯, 右側屈, 右回旋は減少し, 身体 重心は正中に近づいた，実線は，床面と外果前方の垂 直線と耳垂を結んだ線である。

形筋の低緊張が認められた。片脚立位は, 右 5 秒, 左 2 秒であった。

歩行レベルは独歩見守りであった. $10 \mathrm{~m}$ 歩行テスト は20秒，24歩であった，左肩甲骨を徒手的に内転，下 制方向にアライメントを修正して歩行介助を行ったとこ ろ, 左 LR での胸椎の屈曲位, 右側屈位, 右回旋位, 骨 盤左回旋位のアライメントが修正され歩行速度が向上し た. 身体機能は, Brunnstrom Recovery Stage（以下, BRS）が上肢，手指，下肢すべてVであった，梁部感覚 に問題は認めず，表在感覚は殿部，足底で $8 / 10$ で軽度 鈍麻であった。徒手筋力テスト（以下, MMT) は右下 肢がすべて Normal, 左下肢がすべて Good レベルであっ た。関節可動域（以下, ROM）は左肩関節屈曲, 外転 がともに $150^{\circ}$ であり，その他の関節には制限は認めら れなかった。

立位での左肩甲骨のアライメントは，左肩甲骨は外転 位，挙上位，上方回旋位を呈していた。第 8 胸椎〜下角 の距離は立位にてメジャーを用いて測定し, 右 $9.1 \pm 0.1$ $\mathrm{cm}$, 左 $11.6 \pm 0.2 \mathrm{~cm}$ (平均值 \pm 標準偏差) であった. この検査に関しても, 3 回測定を行い平均值を記載した. 左肩関節外転時の肩甲上腕りズムは, 左肩関節外転 0 $10^{\circ}$ にて左肩甲骨外転, 上方回旋が生じ, 先行的に左僧 帽筋上部線維の収縮が感じられた。また全可動域にて, 左僧帽筋上部線維の活動が感じられた。動的な肩甲骨の 安定性を評価する目的で，背卧位にて両上肢を肩関節 $90^{\circ}$ 屈曲位で, 肩甲骨を外転し, 前方方向にリーチ動作 を行わせた，その結果，右上肢と比較し，左上肢は到達 地点の減少と左上肢の動摇が確認された。また左上肢の リーチ時には左僧帽筋上部線維の過剩収縮が認められ た.
3. 病態仮説

本症例は左肩甲骨周囲筋の筋緊張の不均衡により左肩 甲胸郭関節の不安定性を認めたと考える。左肩関節外転 $0 \sim 10^{\circ}$ 時に左肩甲骨の外転，挙上，上方回旋が早期に 生じ, 左肩関節外転 $0 \sim 30^{\circ}$ の setting phase（肩関節外 転初期に僧帽筋中部線維, 前鋸筋下部線維の活動により 肩甲骨の運動が生じない現象 ${ }^{11)}$ ) を認めなかった。ま た左肩関節外転 90〜 $180^{\circ}$ においても肩甲骨外転が過大 であり，左肩甲胸郭関節の不安定を呈していた。それに 加え，肩甲骨の動的な安定性を評価する目的で，背臥位 にて両上肢を肩関節 $90^{\circ}$ 屈曲位で, 肩甲骨を外転させ, 前方方向にリーチ動作を行わせたが，右上肢と比較して 左上肢は到達地点の減少と左上肢の動摇が確認された。 石井 12) は，上肢を空間上に保持するためには前鋸筋と 僧帽筋中部線維, 菱形筋により肩甲骨を胸郭に固定しな がら肩甲骨を外転する必要があると述べている.

以上の先行研究および本症例の評価を踏まえ, 本症例 は僧帽筋中部線維, 下部線維, 菱形筋, 前鋸筋の筋緊張 低下によって左肩甲胸郭関節の不安定性を呈し, 歩行時 に左肩甲骨は外転位を呈したと推察した。

左肩甲胸郭関節の不安定性により立位での体幹アライ メントは, 胸椎屈曲位, 右側屈位, 右回旋位を呈してい た．先行研究では肩甲骨外転と胸椎屈曲角度の相関関係 は確認できたとされていることから ${ }^{4)}$, 本症例において は, 左肩甲骨外転位のアライメントが胸椎の屈曲を生じ させ，体幹アライメントを崩したと考えた。その結果， 歩行時の左 $\mathrm{IC} \sim \mathrm{LR}$ においても左肩甲骨が外転位となり， 胸椎の屈曲位, 右側屈位, 右回旋位を呈し, 重心位置が 左前方に偏位したと推察した。

以上の点を考慮し，立位での体幹アライメントにおい て, 左僧帽筋中部, 下部線維, 前鋸筋, 菱形筋の協調的 な筋活動を生じさせ左肩甲骨を内転, 下制位にアライメ ントを修正することを目指した。また左肩甲骨に付随し て生じている胸椎アライメントを修正し, 歩行能力の改 善を果たすために介入を行った。

\section{4. 方法}

介入時間は 40 分とし, 期間は 5 日間とした。 介入の 詳細を図 3 に示す。初めに前鋸筋，菱形筋の協調的な筋 収縮を獲得する目的で，背臥位にて $200 \mathrm{~g}$ の重錘を把持 して肩甲骨の内外転運動（図 3-a）を10 分間行った. 次に左僧帽筋中部線維, 下部線維, 腹斜筋群への協調的 な筋収縮を獲得する目的で，端座位にて上肢を肩関節外 旋位で前方に接地し，肩甲骨を内転，下制位に保持させ た状態で重心を上肢側へ移動させる介入を 10 分間行っ た（図 3-b). 次に端座位から肩肘位に姿勢を変換させ 僧帽筋中部, 下部線維, 菱形筋の筋収縮を促通すること を目的とした介入を 10 分間行った（図 3-c)．また，セ ラピストが左肩甲骨を介助し左立脚を支持した状態で, 

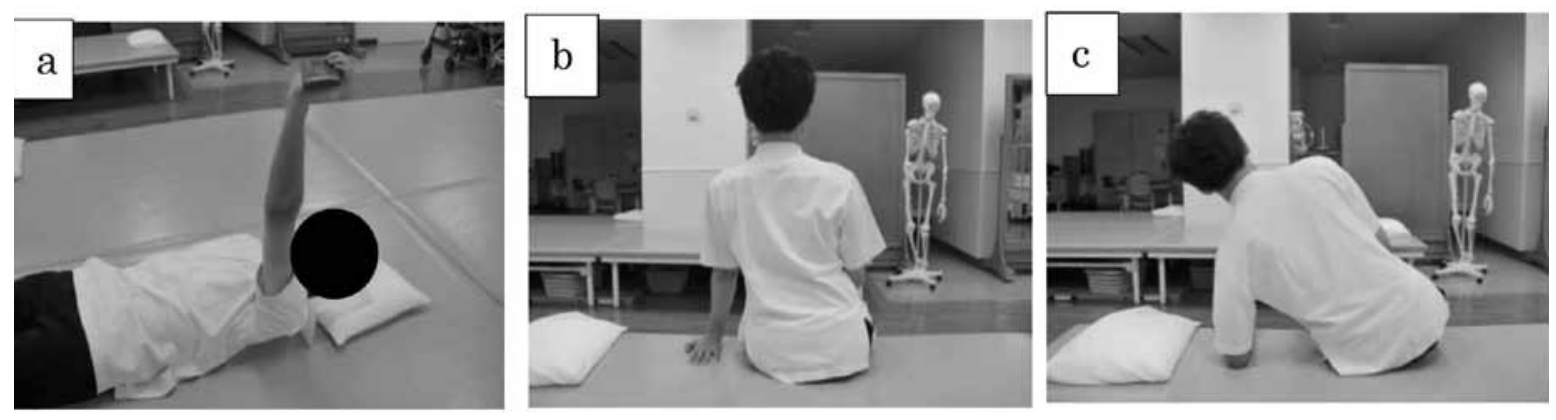

図3 左肩甲胸郭関節の安定化を目指した理学療法プログラム

a. 背臥位にて左肩甲骨の内外転運動を実施．深部感覚入力目的に $200 \mathrm{~g}$ の重錘を把持させた。この時左僧帽筋上部 線維を過剩収縮が生じないように動作を介助した.

b. 端座位にて左前方に左手掌を左肩関節外旋位で接地させ，左肩甲骨を内転，下制位に保持させた状態で左坐骨 への体重移動を促した.

c. 端座位の状態から，肩肘位に姿勢を変換させた，胸椎の後弯，左肩甲骨の外転，下方回旋が生じないように初 めは徒手的に介助した.

表 1 介入前後における評価

\begin{tabular}{lcc}
\hline & 介入前 & 介入 5 日目 \\
\hline 第 1 胸椎〜第 12 胸椎までの & $36.1 \pm 0.1$ & $35.1 \pm 0.2$ \\
距離 $(\mathrm{cm})$ & & \\
第 8 胸椎〜左肩甲骨下角ま & $11.6 \pm 0.2$ & $10.0 \pm 0.4$ \\
での距離 $(\mathrm{cm})$ & $5 / 2$ & $7 / 5$ \\
片脚立位時間 R/L (秒) & 20,24 & 17,21 \\
$10 \mathrm{~m}$ 歩行テスト (秒, 歩数) & 20.21 \\
$\begin{array}{l}\text { 床面と外果前方の垂直線か } \\
\text { ら耳垂までの距離 }(\mathrm{cm})\end{array}$ & $0.5 \pm 0.0$ & $0.3 \pm 0.0$ \\
\hline
\end{tabular}

平均値 \pm 標準偏差.

立位にて側方への重心移動訓練を 5 分間行い, 最後に歩 行訓練を 7 分間実施した。

\section{III. 結 果}

介入前後の結果を表 1 に示す。立位での体幹アライメ ントは，左肩甲骨の外転位，挙上位，上方回旋位，胸椎 の後弯位，右側屈位，右回旋位は改善した（図 2).介 入前後の身体重心の位置の変化を示す床面と外果前方の 垂直線から耳垂までの距離は $0.5 \pm 0.0 \mathrm{~cm}$ から $0.3 \pm$ $0.0 \mathrm{~cm}$ に改善した。立位時の胸椎アライメントを示す 第 1 胸椎〜第 12 胸椎までの距離は, $36.1 \pm 0.1 \mathrm{~cm}$ か ら $35.1 \pm 0.2 \mathrm{~cm}$ に改善した。左僧帽筋中部線維, 下部 線維，左前鋸筋，左菱形筋，左内外腹斜筋の低緊張は改 善した。

左肩甲骨のアライメントに関しては，第 8 胸椎〜下角 までの距離は $11.6 \pm 0.2 \mathrm{~cm}$ から $10.0 \pm 0.4 \mathrm{~cm}$ になり, 左肩甲骨の外転位, 上方回旋位, 挙上位のアライメント は改善した。左肩関節外転時の肩甲上腕リズムは，左肩
関節外転 $20^{\circ}$ で肩甲骨上方回旋，外転が出現し，左肩関 節外転時に生じる左肩甲骨の運動のタイミングは遅延し た。また左肩関節外転時の左僧帽筋上部線維の過剩収縮 は改善した。左肩関節外転, 屈曲の ROM は $150^{\circ}$ から $160^{\circ}$ に改善した。

歩行に関しては，独歩見守りレベルから自立レベルに 向上した. $10 \mathrm{~m}$ 歩行テストは，20 秒から 17 秒，24 歩 から 21 歩に改善した。片脚立位時間は，左下肢 2 秒か ら 5 秒に改善した。 JCS, MMT, BRSにおいては, 変 化がみられなかった。

\section{IV. 考 察}

今回，右前頭葉膠芽腫による左上下肢不全麻痖を呈し た症例に対して，肩甲骨を中心に評価，治療を行ったと ころ, 立位時の左肩甲骨, 胸椎のアライメントが改善し, 歩行能力が改善した.

本症例では，左肩甲胸郭関節の不安定性に対して介入 を行い，立位時の左肩甲骨のアライメントは修正され た。上肢を空間上に保持するためには前鋸筋と僧帽筋中 部線維, 菱形筋により肩甲骨を胸郭に固定しながら肩甲 骨を外転する必要があると報告されている ${ }^{12)}$ ，また肩 甲骨を適切なアライメントに保持するためには，前鋸筋 と僧帽筋上部，中部，下部線維，菱形筋の協調的な筋活 動が必要とされている 13)。本症例は，前鋸筋と僧帽筋 中部，下部線維，菱形筋の筋緊張低下により僧帽筋上部 線維の過剩収縮が生じていた。 そのため, 背臥位にて僧 帽筋上部線維の筋収縮を抑制しながら，前鋸筋と僧帽筋 中部線維, 菱形筋の筋活動を高めた後, 荷重位の状態で 前鋸筋と僧帽筋中部, 下部線維, 菱形筋の筋活動を促し たことで，立位時の左肩甲骨のアライメントが修正され たと考えた。 
さらに立位時の左肩甲骨アライメントの改善により， 胸椎の屈曲が減少し床面と外果前方の垂直線から耳垂ま での距離は $0.5 \pm 0.0 \mathrm{~cm}$ から $0.3 \pm 0.0 \mathrm{~cm}$ と改善し, 身体重心は後方に移動した。肩甲骨外転と胸椎屈曲のア ライメントには相関関係があったと報告されている ${ }^{4,5)}$. また，山口ら 14) は肩甲骨と胸椎の関係性について報告 しており，肩甲骨が内転した場合は胸椎が伸展，外転し た場合は胸椎が屈曲すると述べているが, このメカニズ ムについて言及はなされていない.

肩甲骨のアライメント改善が胸椎のアライメント改善 につながった要因としては，胸郭の関与が考えられる。 柿崎 ${ }^{15)}$ は肩甲骨と胸郭の関係性について，上位胁骨が 後方回旋位である場合, 胸椎は伸展方向に誘導されるが 肩甲骨が外転位であると胸郭のポンプハンドルモーショ ン, バケツハンドルモーションが阻害されるため上位肋 骨の後方回旋が生じにくいと報告している，本症例では， 肩甲骨の内転，下制位にアライメントが修正されたこと により，上位肋骨が後方回旋位に修正され，それに伴い 胸椎の伸展が誘導されたのではないかと推測した。

立位における身体重心の改善により，重心を支持基底 面内に収めるために生じていた股関節アライメントが中 間位に修正された，身体重心が前方に位置している場合， 体幹には前屈モーメントが生じて春柱起立筋が優位に作 用する. 三谷ら 16) は静的立位における仙椎傾斜角が増 大していた者は, 体幹伸展筋力と屈曲筋力の比が体幹伸 展筋力優位であったと報告している，そのため，身体重 心が後方に移動したことにより，脊柱起立筋の活動が抑 制され腹斜筋の活動が促通されたと考えた。

立位における体幹アライメントが修正された状態で立 位バランス訓練，歩行訓練を行ったことにより歩行時の 安定性と効率性が向上し, 独歩自立レベルに至った。歩 行時の腹筋群の筋活動については, IC では外腹斜筋が 骨盤の回旋に対抗して生じる胸郭の回旋を制動し, LR では内腹斜筋が仙腸関節への剪断力を減少させることに よって立脚が安定するといわれている17). 本症例にお いては，立位アライメントを修正した後，立位バランス 訓練, 歩行訓練を行った結果, 筋緊張が改善して適切な タイミングでの筋収縮が可能になったため, 歩行能力が 向上したと考えた.

以上のように本症例では，左肩甲胸郭関節に対して評 価，治療を行うことによって左肩甲骨が内転，下制位へ と修正され歩行能力が向上した，肩甲骨は，体幹のアラ イメントと関連性が強いといわれているため，身体重心 を修正する必要がある場合は，肩甲骨に対して評価，治 療を行うべきであると考えられる。

しかし, 本症例は脳腫瘍摘出術後 3 日目からの介入で あるため, 自然回復の影響も考えられる. Nudo ${ }^{18)}$ は, 脳損傷後 1 力月間は脳浮腫などの改善を認めるため, 自 然回復の影響が大きいと述べている。したがって，本症
例においても介入効果のみではなく, 脳浮腫の改善など 自然回復の影響も含んでいると考えられる.

しかしながら，一般的に膠芽腫は予後不良であり， ADL 改善は困難であるといわれており，本介入効果に よる部分もあったのではないかと考える。膠芽腫は脳組 織への親和性が強く, 脳腫瘍摘出術を行っても腫瘍細胞 のすべてを摘出することは困難であり, 生命予後は 2 年 程度であると報告されている19)。 また百瀬ら 20) は, 脳 腫瘍摘出術後に早期リハビリテーションを行った膠芽腫 患者の入院から退院までの Barthel index（以下，BI）の 改善率を検討しており, 膠芽腫患者の BI の改善率は他 の脳腫瘍患者と比較し低值であったと報告している。つ まり膠芽腫に関しては, 脳損傷後の自然回復が大きいと 報告されている術後 1 カ月間においても ADL は改善し ない可能性が示唆される。したがって，本症例の身体機 能, ADLの改善に関しては, 脳浮腫の改善などに加え, 本介入による部分もあるのではないかと考える.

また, 本研究の限界として, 介入前後の肩甲骨周囲筋, 股関節周囲筋の筋活動，筋緊張検査については客観的な デー夕を示せていないため, 介入効果に関しては推測の 域を出ない。 また今回の介入は, 肩甲骨のみではなく, 立位, 歩行訓練も行っているため, 肩甲骨アライメント の改善のみが胸椎の屈曲の減少を引き起こしたとは断言 できない、それらに加え，今回の報告は一症例のみの報 告であるため, 肩甲骨介入への有効性が頑健であるとは いえない. 今後は, さらに症例数を増やして肩甲骨介入 への有効性を示していく必要がある.

利益相反 開示すべき利益相反はない.

\section{引用文献}

1) 坂光徹彦, 浦辺幸夫 : 脊柱後弯変形とバランス能力および 歩行能力の関係. 理学療法科学, 2007, 22: 489-494.

2) 飯盛仁志：歩行における前傾姿勢が下肢筋の筋活動に及ぼ す変化. 日本医科大学雑誌, 1994, 61: 17-25.

3) 佐久間 亨：体幹の前後傾が歩行動作に及ぼす影響に関す るバイオメカニクス的研究. バイオメカニズム誌，2010, 34: 325-332.

4) 吉田一也, 江尻廣樹 : 自然立位の脊柱アライメントと肩甲 骨位置および肩甲上腕関節外転可動域の関係．理学療法科 学, 2014, 29: 277-282.

5) 市川和奈, 竹井 仁·他:立位における頭部·頸胸椎·肩甲骨· 上肢の姿勢分類. 日本保健学会誌，2013，15: 210-218.

6) 冨田昌夫:片麻痺の肩の痛みに対する理学療法. 理学療法学, 1989, 13: 185-189.

7) 山川諒太, 増田 司：肩甲帯アライメントの変化が脳卒中 片麻痺患者の歩行に及ぼす影響—Gait Judge Systemを用い た検討一. 理学療法東京, 2014, 3: 42-48.

8) 長谷部香織, 伊藤美弥子：肩関節に亜脱臼と疼痛がみられ る脳卒中片麻瘏患者に対する上肢懸垂用肩関節装具才モ 
ニューレクサの使用経験. 理学療法研究, 2012, 29: 39-42.

9) Hesse S: Introduction of new shoulder orthosis to treat shoulder pain in the Severely affected arm in patients during early rehabilitation after Stroke. Neuro Rehabili, 2008, 14: 89-92.

10) 中村隆一, 齋藤 宏·他: 基礎運動学, 第6 版. 医歯薬出版, 東京, 2006, pp331-360.

11) 三浦雄一郎：肩関節屈曲と外転時の肩甲骨運動の特徵と肩 甲帯周囲筋との関連性. 総合リハ, 2009, 37: 649-655.

12) 石井慎一郎：動作分析 臨床活用講座バイオメカニクス に基づく臨床推論の実践. メジカルビュー, 東京, 2013, pp36-119.

13) Neumann DA:筋骨格系のキネシオロジー. 医歯薬出版, 東京, 2005, pp137-188.

14) 山口光图, 福井勉: 結果の出せる整形外科理学療法 運動 連鎖から全身をみる。メジカルビュー, 東京, 2009, pp75176.
15) 柿崎藤泰：胸郭運動システムの再建法, 呼吸運動再構築 理論に基づく評価と治療, 第 1 版. 三輪書店, 東京, 2016 , pp150-179.

16) 三谷保弘，森北育宏：静的立位における矢状面での腰仙椎 アライメントと体幹筋力および下肢筋伸張性との関係. 理 学療法科学, 2008, 23: 35-38.

17) 三浦雄一郎：歩行時の体幹の筋活動. 理学療法学, 2001, 28: 252 .

18) Nudo RJ: Adaptive plasticity in motor cortex: implications for rehabilitation after brain injury. J Rehabil Med, 2003, 41: 7-10.

19) 奈良 勲, 鎌倉矩子: 標準理学療法学·作業療法学 病理学, 第3版. 医学書院, 東京, 2011, pp188-189.

20) 百瀬由佳, 小林一成：脳腫瘍入院患者に対する早期リハビ リテーションの効果. J Rehabil Med, 2007, 44: 745-750. 